\title{
User's Survey of North Indian University Libraries
}

\author{
Rajeev Manhas \\ Baba Farid University of Health \\ Sciences, Faridkot, \\ Punjab, India
}

dr.rajeevmanhas@gmail.com

\author{
lqbal Singh Brar \\ Malout Institute of Management \\ and Information Technology, \\ Malout, Punjab, India
}

librarianmimit@yahoo.com

\begin{abstract}
User survey is necessary for every library because library administrator cannot measure user's satisfaction and cannot understand user's needs with a view to strengthening the depth and breadth of library collections and they cannot make improvement in the library facilities, services and staff. This paper is devoted to ascertain the situation in twelve university libraries towards user's needs, library facilities, and services and staff attitude.
\end{abstract}

Keywords: User Survey; User's Need; Staff Attitude; Library Services; University Libraries; India

\section{Introduction}

The teaching and research have emerged as the basic functions of universities; the role of the university library has also become crucial, intrinsic and academic in nature. Giving due importance to this fact, the University Grants Commission (UGC), since its inception has been providing necessary funds and other support for the growth and development of university libraries. In the process of evolution, the university libraries in India have thrown up various problems, which call for analysis, examination and solution. On the one hand, there is knowledge revolution and perfuse inflow of information, on the other, there is heavy demand for real-time access to quality information. Now the questions arise, users are satisfied to its university libraries, Libraries are understand user's need and improve library facilities, services and staff. The answer of these questions can be taken from the users through user's survey. So, user's survey is necessary for every library otherwise library administrator can not measure user's satisfaction. They can not understand users needs with a view to strengthening the depth and breadth of library collections and can not make improvement in the library facilities, services and staff. Keeping in mind the foregoing discussion, the present study is devoted to ascertain the situation in twelve university libraries towards user's needs, library facilities, services and staff attitude.

Material published as part of this publication, either online or in print, is copyrighted by the Informing Science Institute. Permission to make digital or paper copy of part or all of these works for personal or classroom use is granted without fee provided that the copies are not made or distributed for profit or commercial advantage AND that copies 1) bear this notice in full and 2) give the full citation on the first page. It is permissible to abstract these works so long as credit is given. To copy in all other cases or to republish or to post on a server or to redistribute to lists requires specific permission and payment of a fee. Contact Publisher@InformingScience.org to request redistribution permission.

\section{Objectives of the Study}

1. To know the awareness of the users about the library resources, facilities and services.

2. To know the collection wise rating of the libraries according to the users.

3 . To know the overall organizational set up of the libraries. 
4. To know the adequacy of library resources and material relation to requirement of the users.

\section{Scope and Limitations of the Study}

This study is limited to 12 central university libraries in North Region of India excluding Deemed and Specialized (Technical, Medical and Agriculture) university libraries. These universities are closely a homogenous group, as they provide almost similar courses. The names of the universities are: University of Delhi, Delhi (DU); Jawaharlal Nehru University, New Delhi (JNU); Guru Nanak Dev University, Amritsar (GNDU); University of Kashmir, Sri Nagar (KU); University of Jammu, Jammu (JU); Maharishi Dayanand Sarawati University, Ajmer (MDSU); University of Rajasthan, Jaipur (RU); Punjabi University, Patiala (Pbi U); Kurukshetra University, Kurukshetra (KUK); Himachal Pardesh University, Shimla (HPU); Panjab University, Chandigarh (PU) and Maharishi Dayanand University, Rohtak (MDU). This study is also limited in the sense that the respondents have given their views in the situation prevailing at the time of survey.

\section{Research Methodology}

This study is based on the comprehensive survey of 12 university libraries in the North region of India. Secondary data is also used to supplement the results wherever possible. The primary data was collected from sample university libraries through personal visits by contacting users of the libraries through a drafted questionnaire and this questionnaire was circulated to 1200 users of these 12 university libraries, out of which 881 responded. 100 questionnaires were distributed in each university randomly by selecting 20 respondents in each category (students, researchers, teachers, non teaching staff, and others).

\section{Data Analysis and Presentations}

This study deals with the optimum use of library resources, facilities and services.

\section{Users Awareness}

So far as the awareness of library resources, facilities and services by various categories of the users is concerned, it found to be highly significant. Table 1 indicates that the awareness level is significantly different among the different users. This is evident from the fact that value of Chi square variate is highly significant at 4 degree of freedom.

\begin{tabular}{|l|l|l|l|}
\hline \multicolumn{4}{|c|}{ Table 1: User Awareness of Library Resources, Facilities and Services } \\
\hline & \multicolumn{2}{|c|}{ Awareness Level } & \\
\hline CATEGORY & FULLY & PARTIALLY & TOTAL \\
\hline Students & 90 & 141 & 231 \\
\hline Researchers & 214 & 8 & 222 \\
\hline Teachers & 161 & 32 & 193 \\
\hline Non- Teaching & 40 & 122 & 162 \\
\hline Others & 12 & 61 & 73 \\
\hline Total & 517 & 364 & 881 \\
\hline
\end{tabular}

Table 2 elaborates the user level of use of concerned library. Table 2 speaks of percentage of library facilities used by the beneficiaries. 


\begin{tabular}{|c|c|c|c|c|c|c|c|c|}
\hline \multicolumn{9}{|c|}{ Table 2: Extent of Library Use } \\
\hline \multirow[t]{2}{*}{ USER/ USE } & \multicolumn{2}{|c|}{ MAXIMUM } & \multicolumn{4}{|c|}{ LIMITED } & \multicolumn{2}{|c|}{ NOT } \\
\hline & & \%age & \begin{tabular}{|l|} 
Short \\
time of \\
the user
\end{tabular} & $\begin{array}{l}\text { Material } \\
\text { shortage in } \\
\text { the library }\end{array}$ & $\begin{array}{l}\text { Total Lim- } \\
\text { ited }\end{array}$ & $\%$ age & & \%age \\
\hline Students & 114 & 49.35 & 56 & 54 & 110 & 47.61 & 7 & 3.04 \\
\hline Researchers & 202 & 91.1 & 4 & 8 & 12 & 5.4 & 8 & 3.5 \\
\hline Teachers & 164 & 85.2 & 12 & 17 & 29 & 15.02 & 0 & 0 \\
\hline Non Teaching Staff & 29 & 17.9 & 91 & 42 & 133 & 82.1 & 0 & 0 \\
\hline Others & 41 & 56.12 & 23 & 8 & 31 & 42.46 & 1 & 1.42 \\
\hline Total & 550 & 62.42 & 186 & 129 & 315 & 35.75 & 16 & 1.83 \\
\hline
\end{tabular}

Out of total 881 users 550 users are using the library resources maximum and the percentage comes to $62.42 \%$. Limited use of library stands at $35.75 \%$. Reasons for limited include shortage of time of the user (186 users) and material shortage in the concerned library (129). The rest of the 16 users who do not use the library resources, their percentage is meager $(1.83 \%)$. They are of the view that the resources available with the library concerned are not in consonance with their needs and they are not catering their requirements to meet their ends.

\section{User Rating of Library Collection}

Table 3 speaks of average rating of individual library by the users according to their collection.

\begin{tabular}{|l|l|l|l|l|l|l|l|}
\hline \multicolumn{9}{|l|}{ Table 3: User Rating of Library Collection } \\
\hline $\begin{array}{l}\text { UNIV./USE } \\
\text { RS }\end{array}$ & $\begin{array}{l}\text { STU- } \\
\text { DENTS }\end{array}$ & $\begin{array}{l}\text { RESEARCH- } \\
\text { ERS }\end{array}$ & $\begin{array}{l}\text { TEACH- } \\
\text { ERS }\end{array}$ & $\begin{array}{l}\text { NON- } \\
\text { TEACH- } \\
\text { ING } \\
\text { STAFF }\end{array}$ & $\begin{array}{l}\text { OTH- } \\
\text { ERS }\end{array}$ & $\begin{array}{l}\text { AVER- } \\
\text { ER- } \\
\text { AGE }\end{array}$ & S.D. \\
\hline PU & 3.87 & 3.32 & 3.75 & 3.61 & 3.86 & 3.68 & 0.23 \\
\hline DU & 3.84 & 3.65 & 3.85 & 3.74 & 3.69 & 3.75 & 0.09 \\
\hline JNU & 4.08 & 3.78 & 3.85 & 3.53 & 3.86 & 3.82 & 0.20 \\
\hline KU & 3.93 & 3.82 & 3.91 & 3.80 & 3.81 & 3.85 & 0.06 \\
\hline MDU & 3.98 & 3.86 & 4.02 & 3.72 & 4.19 & 3.95 & 0.18 \\
\hline HPU & 3.81 & 3.80 & 3.78 & 3.70 & 4.09 & 3.84 & 0.15 \\
\hline JU & 4.11 & 3.86 & 4.11 & 4.16 & 3.92 & 4.03 & 0.13 \\
\hline Kash. U & 4.10 & 4.15 & 4.05 & 3.75 & 3.75 & 3.96 & 0.19 \\
\hline GNDU & 3.76 & 3.63 & 3.82 & 3.90 & 3.90 & 3.80 & 0.11 \\
\hline Pbi. U & 3.85 & 3.79 & 3.93 & 3.73 & 4.06 & 3.87 & 0.13 \\
\hline RU & 3.64 & 3.64 & 3.84 & 3.48 & 3.88 & 3.70 & 0.16 \\
\hline MDSU & 3.18 & 3.10 & 3.22 & 3.24 & 3.25 & 3.20 & 0.06 \\
\hline
\end{tabular}

The ratings of users have been carried out on 5 point Liker Scale and the results show that the University of Jammu stands at number 1 with having 4.03 average points. This library is followed by University of Kashmir (3.96) and Maharishi Dayanand University (3.95). The Standard Deviation figure of University of Jammu is 0.13 which also reveals that all the users are in agreements 
to the average drawn. The average rating of users of individual library pertaining to their collection wise has been delineated in the Appendix A.

\section{User Rating of Individual Library According to their Organizational Setup}

The data is given in Table 4 regarding the rating of the university libraries of their organizational setup which also includes staff and their services.

\begin{tabular}{|c|c|c|c|c|c|c|c|}
\hline \multicolumn{8}{|c|}{$\begin{array}{l}\text { Table 4: User Rating of Individual Library According to their Organizational } \\
\text { Setup }\end{array}$} \\
\hline UNIV./USERS & $\begin{array}{l}\text { STU- } \\
\text { DENTS }\end{array}$ & $\begin{array}{l}\text { RESEARCH } \\
\text { SEARCH- } \\
\text { ERS }\end{array}$ & $\begin{array}{l}\text { TEACH- } \\
\text { ERS }\end{array}$ & $\begin{array}{l}\text { NON- } \\
\text { TEACH- } \\
\text { ING } \\
\text { STAFF }\end{array}$ & $\begin{array}{l}\text { OTH- } \\
\text { ERS }\end{array}$ & $\begin{array}{l}\text { AVER- } \\
\text { ER- } \\
\text { AGE }\end{array}$ & S.D. \\
\hline \multicolumn{8}{|l|}{ PU } \\
\hline Books Division & 4.37 & 3.62 & 3.91 & 3.83 & 3.83 & 3.91 & 0.28 \\
\hline $\begin{array}{l}\text { Reference Divi- } \\
\text { sion }\end{array}$ & 4.28 & 3.52 & 3.39 & 4.33 & 3.53 & 3.81 & 0.46 \\
\hline $\begin{array}{l}\text { Periodicals Divi- } \\
\text { sion }\end{array}$ & 4.22 & 3.75 & 3.87 & 3.46 & 3.33 & 3.73 & 0.35 \\
\hline $\begin{array}{l}\text { Dissertations Di- } \\
\text { vision }\end{array}$ & 4.38 & 4.12 & 4.26 & 4.67 & 4.53 & 4.39 & 0.22 \\
\hline $\begin{array}{l}\text { Audio Visual Di- } \\
\text { vision }\end{array}$ & 3.78 & 2.75 & 2.93 & 3.20 & 3.00 & 3.13 & 0.40 \\
\hline Others Division & 3.77 & 3.57 & 3.63 & 3.63 & 3.89 & 3.70 & 0.13 \\
\hline \multicolumn{8}{|l|}{ DU } \\
\hline Books Division & 3.72 & 3.72 & 3.86 & 4.23 & 4.25 & 3.96 & 0.27 \\
\hline $\begin{array}{l}\text { Reference Divi- } \\
\text { sion }\end{array}$ & 4.10 & 3.70 & 3.69 & 3.87 & 3.67 & 3.81 & 0.18 \\
\hline $\begin{array}{l}\text { Periodicals Divi- } \\
\text { sion }\end{array}$ & 4.12 & 3.73 & 3.72 & 3.63 & 3.83 & 3.81 & 0.19 \\
\hline $\begin{array}{l}\text { Dissertations Di- } \\
\text { vision }\end{array}$ & 3.72 & 3.55 & 3.81 & 4.10 & 3.67 & 3.77 & 0.21 \\
\hline $\begin{array}{l}\text { Audio Visual Di- } \\
\text { vision }\end{array}$ & 3.62 & 3.40 & 3.33 & 3.33 & 2.92 & 3.32 & 0.25 \\
\hline Others Division & 4.12 & 3.73 & 3.72 & 3.30 & 3.50 & 3.67 & 0.31 \\
\hline \multicolumn{8}{|l|}{ JNU } \\
\hline Books Division & 4.13 & 3.97 & 4.00 & 3.91 & 4.06 & 4.01 & 0.08 \\
\hline $\begin{array}{l}\text { Reference Divi- } \\
\text { sion }\end{array}$ & 4.13 & 3.97 & 4.00 & 3.91 & 4.06 & 4.01 & 0.08 \\
\hline $\begin{array}{l}\text { Periodicals Divi- } \\
\text { sion }\end{array}$ & 3.40 & 3.25 & 3.24 & 3.91 & 4.03 & 3.57 & 0.38 \\
\hline $\begin{array}{l}\text { Dissertations Di- } \\
\text { vision }\end{array}$ & 4.13 & 3.97 & 4.00 & 3.91 & 4.06 & 4.01 & 0.08 \\
\hline $\begin{array}{l}\text { Audio Visual Di- } \\
\text { vision }\end{array}$ & 3.53 & 3.40 & 3.33 & 3.30 & 3.33 & 3.38 & 0.09 \\
\hline Others Division & 4.08 & 4.03 & 4.02 & 3.97 & 4.22 & 4.06 & 0.10 \\
\hline \multicolumn{8}{|l|}{ KU } \\
\hline Books Division & 4.00 & 4.02 & 4.06 & 3.96 & 4.00 & 4.01 & 0.04 \\
\hline
\end{tabular}




\begin{tabular}{|c|c|c|c|c|c|c|c|}
\hline $\begin{array}{l}\text { Reference Divi- } \\
\text { sion }\end{array}$ & 3.97 & 4.02 & 4.06 & 3.96 & 4.00 & 4.00 & 0.04 \\
\hline $\begin{array}{l}\text { Periodicals Divi- } \\
\text { sion }\end{array}$ & 3.93 & 4.11 & 4.00 & 3.91 & 4.33 & 4.06 & 0.17 \\
\hline $\begin{array}{l}\text { Dissertations Di- } \\
\text { vision }\end{array}$ & 4.05 & 4.04 & 4.04 & 3.96 & 4.00 & 4.02 & 0.04 \\
\hline $\begin{array}{l}\text { Audio Visual Di- } \\
\text { vision }\end{array}$ & 3.43 & 3.35 & 3.43 & 3.52 & 2.83 & 3.31 & 0.28 \\
\hline Others Division & 4.00 & 3.96 & 3.98 & 3.96 & 4.50 & 4.08 & 0.24 \\
\hline \multicolumn{8}{|l|}{ MDU } \\
\hline Books Division & 3.90 & 3.97 & 4.19 & 4.24 & 4.33 & 4.13 & 0.18 \\
\hline $\begin{array}{l}\text { Reference Divi- } \\
\text { sion }\end{array}$ & 3.83 & 3.90 & 4.17 & 4.20 & 4.33 & 4.09 & 0.21 \\
\hline $\begin{array}{l}\text { Periodicals Divi- } \\
\text { sion }\end{array}$ & 3.97 & 4.07 & 4.31 & 4.29 & 4.33 & 4.19 & 0.16 \\
\hline $\begin{array}{l}\text { Dissertations Di- } \\
\text { vision }\end{array}$ & 3.88 & 3.92 & 4.13 & 4.16 & 4.50 & 4.12 & 0.25 \\
\hline $\begin{array}{l}\text { Audio Visual Di- } \\
\text { vision }\end{array}$ & 3.20 & 3.22 & 3.50 & 3.51 & 3.83 & 3.45 & 0.26 \\
\hline Others Division & 3.10 & 2.98 & 3.23 & 3.24 & 3.50 & 3.21 & 0.19 \\
\hline \multicolumn{8}{|l|}{ HPU } \\
\hline Books Division & 4.25 & 4.24 & 4.31 & 4.28 & 4.06 & 4.23 & 0.10 \\
\hline $\begin{array}{l}\text { Reference Divi- } \\
\text { sion }\end{array}$ & 4.15 & 4.02 & 4.09 & 4.07 & 3.94 & 4.05 & 0.08 \\
\hline $\begin{array}{l}\text { Periodicals Divi- } \\
\text { sion }\end{array}$ & 4.08 & 4.11 & 3.96 & 3.96 & 4.00 & 4.02 & 0.07 \\
\hline $\begin{array}{l}\text { Dissertations Di- } \\
\text { vision }\end{array}$ & 4.40 & 4.33 & 4.11 & 4.13 & 4.55 & 4.30 & 0.19 \\
\hline $\begin{array}{l}\text { Audio Visual Di- } \\
\text { vision }\end{array}$ & 3.32 & 3.53 & 3.44 & 3.20 & 3.18 & 3.33 & 0.15 \\
\hline Others Division & 4.03 & 4.20 & 3.83 & 3.96 & 3.79 & 3.96 & 0.16 \\
\hline \multicolumn{8}{|l|}{ JU } \\
\hline Books Division & 3.95 & 3.93 & 3.90 & 4.46 & 3.67 & 3.98 & 0.29 \\
\hline $\begin{array}{l}\text { Reference Divi- } \\
\text { sion }\end{array}$ & 3.95 & 3.93 & 3.83 & 4.25 & 3.67 & 3.93 & 0.21 \\
\hline $\begin{array}{l}\text { Periodicals Divi- } \\
\text { sion }\end{array}$ & 3.93 & 3.90 & 3.90 & 4.29 & 3.83 & 3.97 & 0.18 \\
\hline $\begin{array}{l}\text { Dissertations Di- } \\
\text { vision }\end{array}$ & 3.95 & 3.92 & 3.94 & 4.46 & 4.00 & 4.05 & 0.23 \\
\hline $\begin{array}{l}\text { Audio Visual Di- } \\
\text { vision }\end{array}$ & 2.67 & 2.62 & 2.69 & 3.08 & 3.33 & 2.88 & 0.31 \\
\hline Others Division & 3.95 & 3.88 & 3.92 & 4.42 & 3.89 & 4.01 & 0.23 \\
\hline \multicolumn{8}{|l|}{ Kash.U } \\
\hline Books Division & 4.22 & 3.91 & 3.81 & 3.78 & 4.00 & 3.94 & 0.18 \\
\hline $\begin{array}{l}\text { Reference Divi- } \\
\text { sion }\end{array}$ & 4.25 & 4.15 & 4.12 & 4.33 & 4.00 & 4.17 & 0.13 \\
\hline $\begin{array}{l}\text { Periodicals Divi- } \\
\text { sion }\end{array}$ & 4.17 & 3.91 & 3.83 & 3.78 & 4.00 & 3.94 & 0.15 \\
\hline $\begin{array}{l}\text { Dissertations Di- } \\
\text { vision }\end{array}$ & 4.19 & 3.88 & 3.90 & 3.67 & 4.00 & 3.93 & 0.19 \\
\hline $\begin{array}{l}\text { Audio Visual Di- } \\
\text { vision }\end{array}$ & 3.08 & 2.82 & 2.69 & 2.56 & 2.33 & 2.70 & 0.28 \\
\hline Others Division & 4.11 & 4.03 & 3.83 & 3.89 & 4.00 & 3.97 & 0.11 \\
\hline
\end{tabular}


User's Survey of North Indian University Libraries

\begin{tabular}{|c|c|c|c|c|c|c|c|}
\hline GNDU & & & & & & & \\
\hline Books Division & 3.87 & 3.90 & 3.93 & 3.67 & 3.80 & 3.83 & 0.10 \\
\hline $\begin{array}{l}\text { Reference Divi- } \\
\text { sion }\end{array}$ & 3.87 & 3.88 & 3.83 & 3.72 & 3.87 & 3.83 & 0.07 \\
\hline $\begin{array}{l}\text { Periodicals Divi- } \\
\text { sion }\end{array}$ & 3.87 & 4.00 & 3.95 & 3.61 & 3.60 & 3.81 & 0.19 \\
\hline $\begin{array}{l}\text { Dissertations Di- } \\
\text { vision }\end{array}$ & 3.93 & 3.95 & 4.03 & 3.94 & 4.07 & 3.98 & 0.06 \\
\hline $\begin{array}{l}\text { Audio Visual Di- } \\
\text { vision }\end{array}$ & 2.68 & 2.90 & 2.83 & 2.67 & 2.60 & 2.74 & 0.12 \\
\hline Others Division & 3.87 & 3.88 & 3.88 & 3.94 & 4.00 & 3.91 & 0.06 \\
\hline \multicolumn{8}{|l|}{ Pbi. U } \\
\hline Books Division & 3.90 & 3.87 & 4.04 & 3.94 & 4.40 & 4.03 & 0.22 \\
\hline $\begin{array}{l}\text { Reference Divi- } \\
\text { sion }\end{array}$ & 4.07 & 4.08 & 4.33 & 4.24 & 4.33 & 4.21 & 0.13 \\
\hline $\begin{array}{l}\text { Periodicals Divi- } \\
\text { sion }\end{array}$ & 4.13 & 4.15 & 4.31 & 4.22 & 4.53 & 4.27 & 0.16 \\
\hline $\begin{array}{l}\text { Dissertations Di- } \\
\text { vision }\end{array}$ & 3.85 & 3.87 & 4.80 & 3.94 & 3.97 & 4.09 & 0.40 \\
\hline $\begin{array}{l}\text { Audio Visual Di- } \\
\text { vision }\end{array}$ & 3.07 & 3.17 & 3.27 & 3.14 & 3.37 & 3.20 & 0.12 \\
\hline Others Division & 4.08 & 4.08 & 4.29 & 4.20 & 4.40 & 4.21 & 0.14 \\
\hline \multicolumn{8}{|l|}{ RU } \\
\hline Books Division & 4.17 & 4.25 & 3.95 & 3.64 & 4.00 & 4.00 & 0.24 \\
\hline $\begin{array}{l}\text { Reference Divi- } \\
\text { sion }\end{array}$ & 4.35 & 4.25 & 4.03 & 3.69 & 4.00 & 4.06 & 0.26 \\
\hline $\begin{array}{l}\text { Periodicals Divi- } \\
\text { sion }\end{array}$ & 2.80 & 2.70 & 2.85 & 2.60 & 4.00 & 2.99 & 0.57 \\
\hline $\begin{array}{l}\text { Dissertations Di- } \\
\text { vision }\end{array}$ & 3.47 & 3.47 & 3.77 & 3.60 & 4.00 & 3.66 & 0.23 \\
\hline $\begin{array}{l}\text { Audio Visual Di- } \\
\text { vision }\end{array}$ & 3.33 & 3.38 & 3.69 & 3.12 & 4.00 & 3.50 & 0.34 \\
\hline Others Division & 4.28 & 4.27 & 3.97 & 3.43 & 4.00 & 3.99 & 0.35 \\
\hline \multicolumn{8}{|l|}{ MDSU } \\
\hline Books Division & 3.65 & 3.74 & 3.96 & 4.14 & 4.00 & 3.90 & 0.20 \\
\hline $\begin{array}{l}\text { Reference Divi- } \\
\text { sion }\end{array}$ & 3.77 & 3.94 & 4.13 & 4.02 & 3.78 & 3.93 & 0.16 \\
\hline $\begin{array}{l}\text { Periodicals Divi- } \\
\text { sion }\end{array}$ & 3.77 & 3.67 & 3.84 & 3.95 & 3.89 & 3.82 & 0.11 \\
\hline $\begin{array}{l}\text { Dissertations Di- } \\
\text { vision }\end{array}$ & 3.98 & 4.06 & 3.96 & 3.95 & 3.67 & 3.92 & 0.15 \\
\hline $\begin{array}{l}\text { Audio Visual Di- } \\
\text { vision }\end{array}$ & 3.00 & 3.00 & 3.00 & 3.00 & 3.00 & 3.00 & 0.00 \\
\hline Others Division & 3.00 & 3.00 & 3.00 & 3.00 & 3.00 & 3.00 & 0.00 \\
\hline
\end{tabular}

The above data indicates that on the basis of average rating for organizational setup of the individual library by the users, the Himachal Pradesh University is excellent and Guru Nanak Dev University is good in book division, Punjabi University is Excellent in the reference division while Panjab University and University of Delhi are rated as good. The Maharishi Dayanand University and Panjab University are Excellent in periodical and dissertation divisions whereas University of Rajasthan is average and good respectively. In the organizational setup of the audio-visual division, the University of Rajasthan is good and University of Kashmir is average. 
The average rating of users of individual library pertaining to their organizational set up, staff and services wise have been delineated in the Appendix B.

\section{Library Fulfillment of the Requirement of its Users}

Table 5 and Figure 1 show that how much library fulfills the requirement of its users.

\begin{tabular}{|l|l|l|l|l|l|l|}
\hline \multicolumn{7}{|c|}{ Table 5: Users' Perception of Needs Fulfillment } \\
\hline USERS & FULLY & \%AGE & PARTIAL & \%AGE & NOT & \%AGE \\
\hline Students & 60 & 25.97 & 168 & 72.73 & 3 & 1.3 \\
\hline Researchers & 1 & 0.45 & 195 & 87.84 & 26 & 11.71 \\
\hline Teachers & 1 & 0.52 & 181 & 93.78 & 11 & 5.7 \\
\hline Non- Teaching Staff & 2 & 1.23 & 137 & 84.57 & 23 & 14.2 \\
\hline Others & 7 & 9.59 & 66 & 90.41 & 0 & 0 \\
\hline Total & 71 & 8.06 & 747 & 84.79 & 63 & 7.15 \\
\hline
\end{tabular}

Regarding users satisfaction, $8.06 \%$ are fully satisfied with its library whereas $84.79 \%$ are partially satisfied and the rest $7.15 \%$ are not satisfied with its respective library.

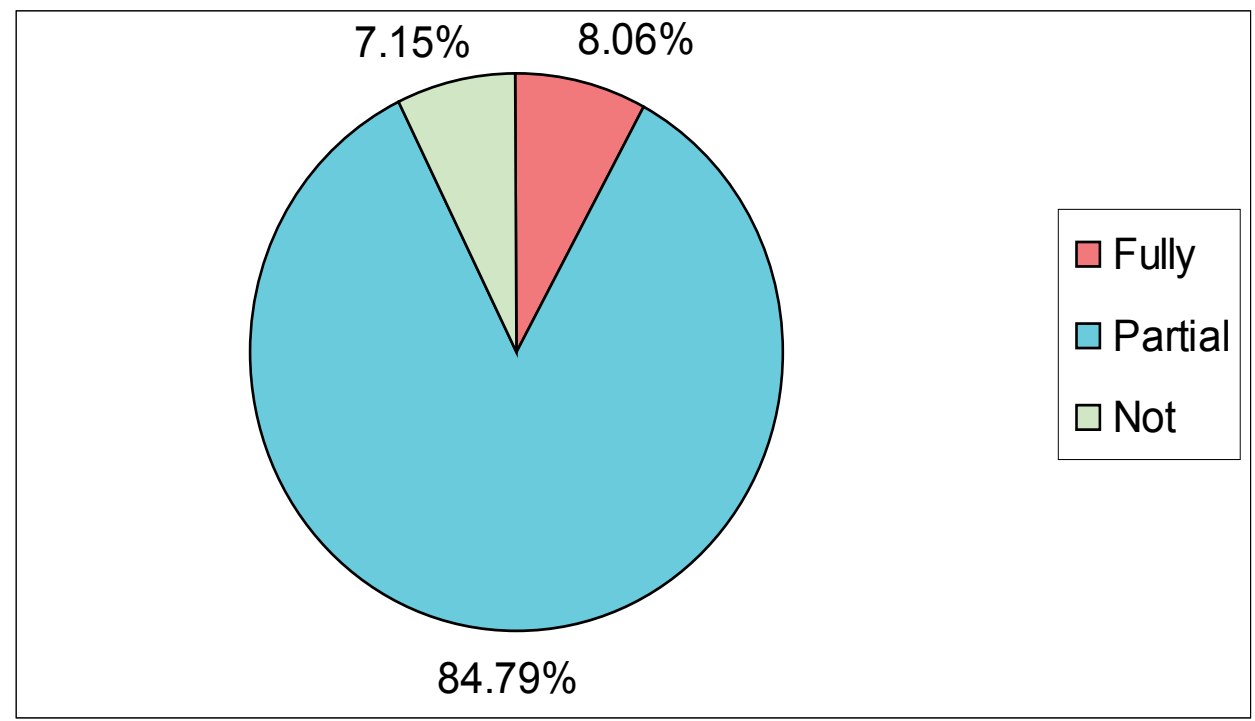

Figure 1: Pie Chart Showing Library Fulfillment of the Requirement of the User

The above data indicates that the present situation of the libraries and their cooperative activities are not fully satisfying its users.

\section{Conclusion}

So far as the awareness of various categories of the users is concerned, it is found to be highly significant. This indicates that the awareness level is significantly different among the different categories of users. This is evident from the fact that value of Chi square variate is highly significant. 
The maximum use of library by $62.42 \%$ of the users, $35.75 \%$ of the users' make limited use of library due to time shortage with the users and material shortage with the respected library. The rest of the users $(1.83 \%)$ make no use of library because the library resources and services are not according to their information needs.

Out of all university libraries, the Jammu University has the highest overall collection rating and Maharishi Dayanand Sarswati University has the lowest overall collection rating as reported by the users.

On the basis of average rating for organizational setup of the individual library by the users, the Himachal Pradesh University is excellent and Guru Nanak Dev University is good in book division, Punjabi University is Excellent in the reference division, while Punjab University and University of Delhi are rated as good. The Maharishi Dayanand University and Panjab University are Excellent in periodical and dissertation divisions, whereas University of Rajasthan is average and good respectively. In the organizational setup of the audio visual division, the University of Rajasthan is good and the University of Kashmir is average.

Regarding users' satisfaction, $8.06 \%$ are fully satisfied with their library whereas $84.79 \%$ are partially satisfied and the rest of $7.15 \%$ are not satisfied with their respective library.

\section{Suggestions}

As the users are not fully aware of the overall library collections and services, orientation programme must be organized to make these users aware of the library collection and its services. Users should also be aware of the library digital resources, resource sharing and networking, and must have knowledge regarding the particular network to which their library is connected.

Library collection development should be according to the needs of the users. In this regard suggestions from the users should be considered for purchase of library material.

Library organizational setup, staff and their services should be strengthened. If the library material is not organized, then user can not obtain the required information easily. Library staff should be cooperative, informative, qualified and better information provider so that library can provide better services to its users.

\section{References}

Allen, K. W. (1970). An investigation of students and faculty attitudes and their utilization of the community college library in three selected colleges with in Illinois University. Ph.D. Thesis, Illinois University.

Fink, A., \& Kosecoff, J. B. (1998). How to conduct surveys: A step by step guide (2nd ed.). Thousand Oaks, CA, USA: Sage.

Unomah, J. I. (1985). Student utilization of academic libraries in Nigeria: An assessment. Journal of Library and Information Science, 10(2), 170-182. 


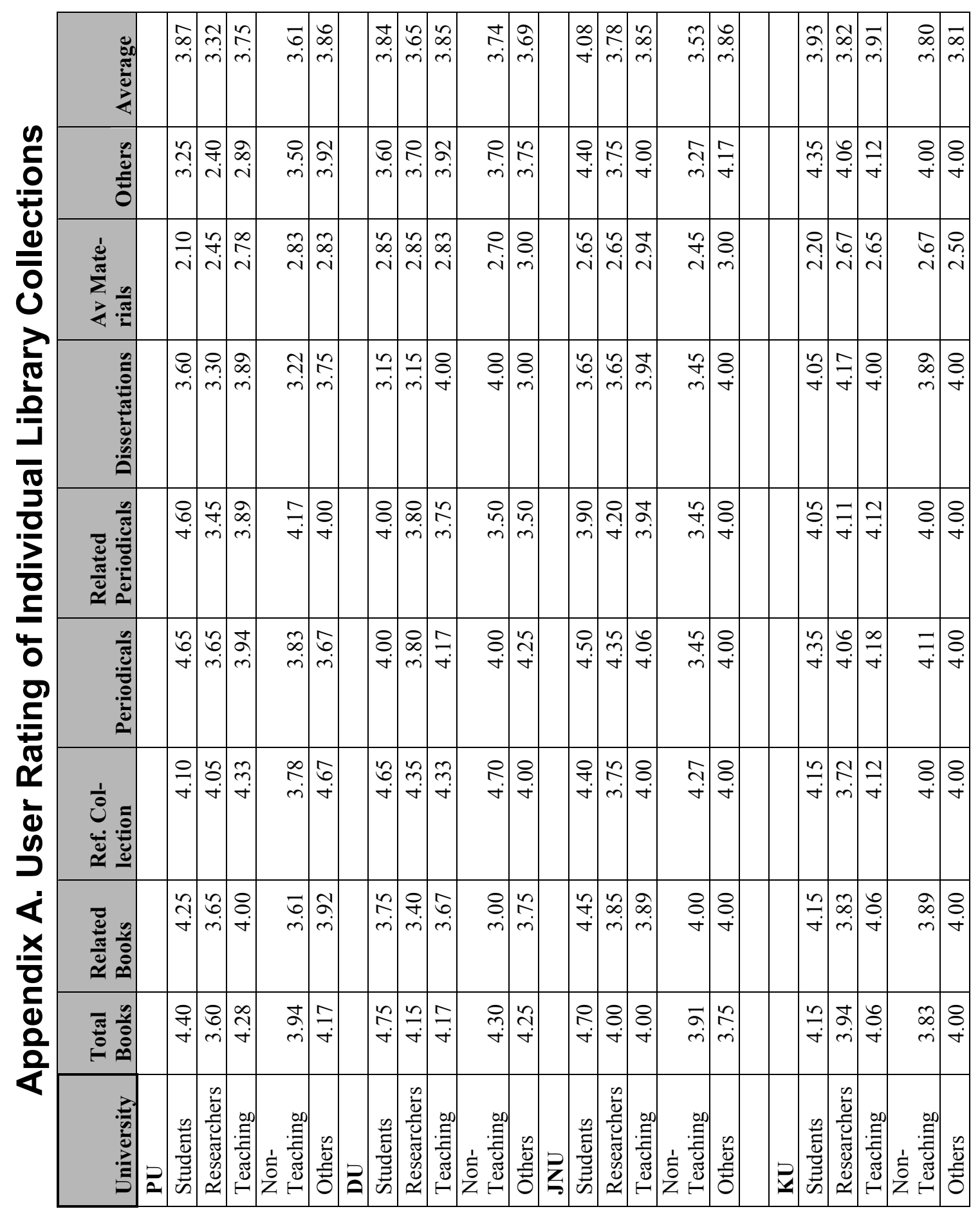




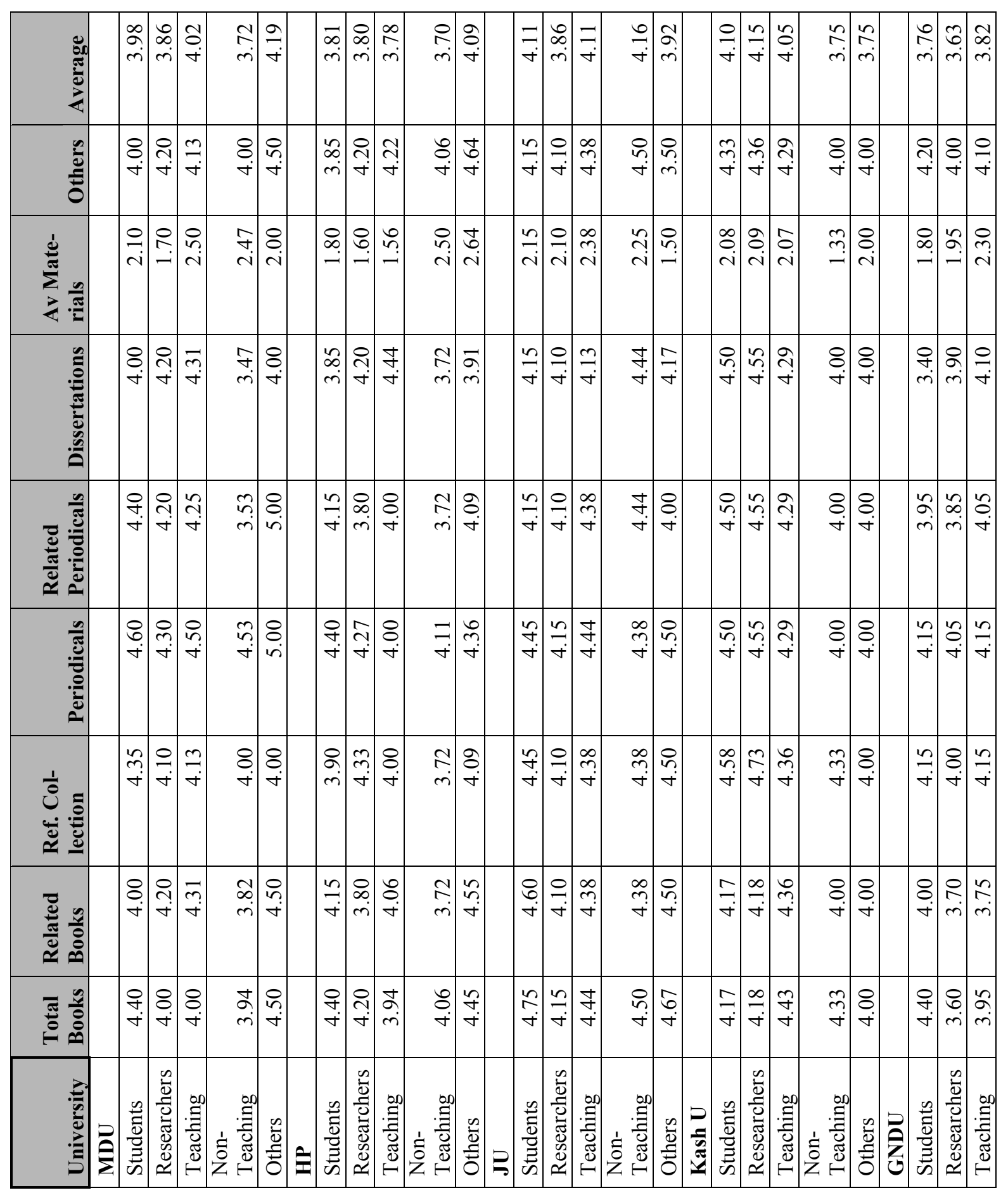




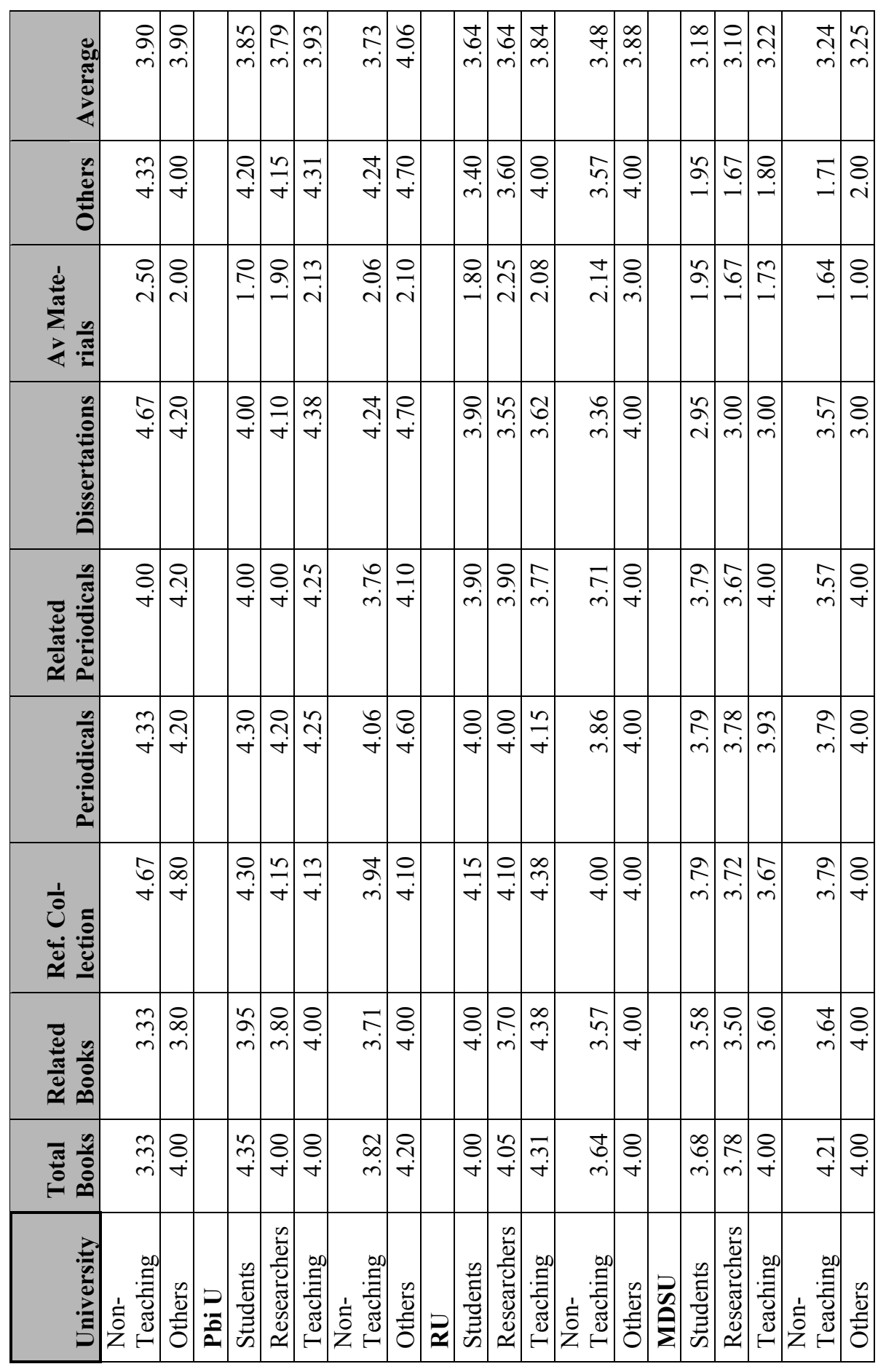




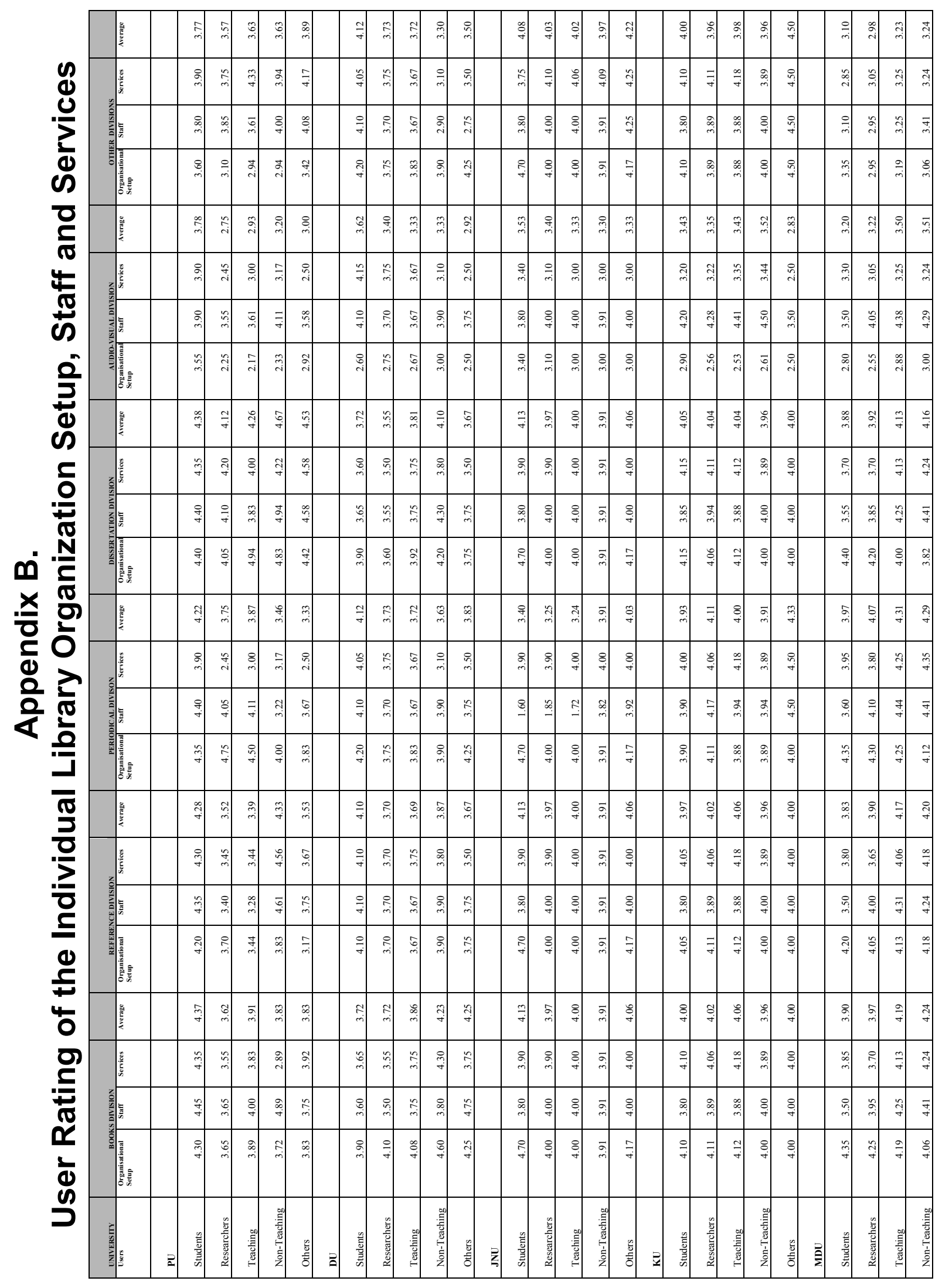




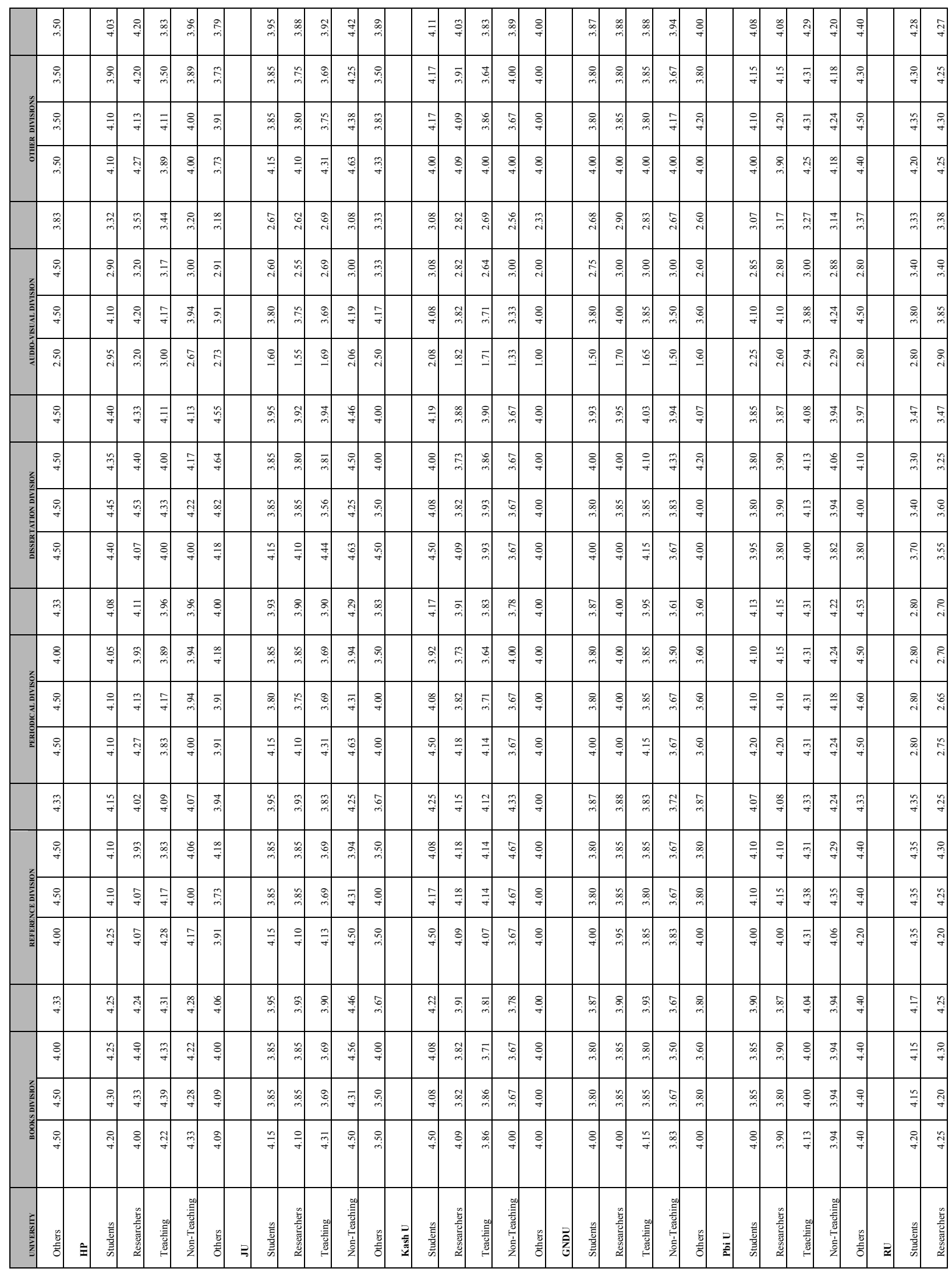




$$
\mathbb{\|}
$$




\section{Biographies}

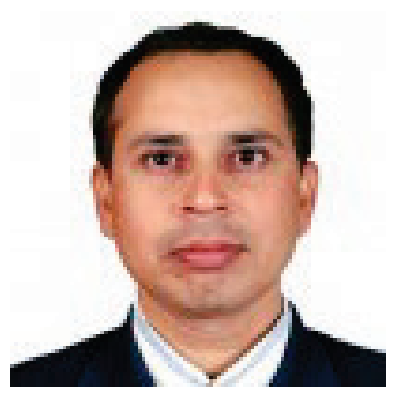

Rajeev Manhas, Ph.D. (LISc), AMSPI, FUWAI, is Head of Department of Health Sciences Library \& Information System and University Library, BFUHS, Faridkot, Punjab, India. He has more than 17 years work experience in librarianship. He has attended more than 50 conferences inculding international conference at Canada. He has published more than 50 research papers in national and inernational journals, 4 books and 7 chapters in books. He has young scientist award-2011 to his credit for his contribution in development of health sciences library network in Punjab. He is on the editorial baord of 5 international and 4 national journals.

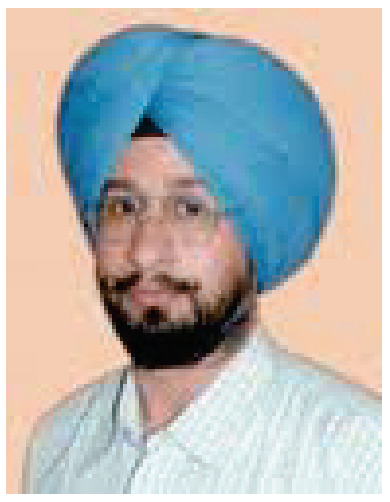

Iqbal Singh Brar, Ph.D. (LISc), is Librarian of Malout Institute of Management \& Information Technology, Malout, Punjab, India. He has more than 18 years work experience in librarianship. He has attended more than 40 conferences. He has published more than 20 research papers in national and inernational journals, 3 books and 3 chapters in books. 